and colors of the zebra-like stripes with which they must be decorated, and even the days of arrival and departure as well as the number of sailings.

To this memorandum there was only one possible answer. On February 3 the Secretary of State addressed a note to the German Ambassador recalling the correspondence concerning the Sussex and concluding in the following language:

In view of this declaration (that all ships met within the zones will be sunk), which withdraws suddenly and without prior intimation the solemn assurance given in the Imperial Government's note of May 4, 1916, this Government has no alternative consistent with the dignity and honor of the United States but to take the course which it explicitly announced in its note of April 18, 1916, it would take in the event that the Imperial Government did not declare foffect an abandonment of the methods of submarine warfare then employed and to which the Imperial Government now purpose again to resort.

The President has, therefore, directed me to announce to Your Excellency that all diplomatic relations between the United States and the German Empire are severed, and that the American ambassador at Berlin will be immediately withdrawn and in accordance with such announcement to deliver to Your Excellency your passports.

Thus officially terminated a relation of friendship which had long been sincerely cherished, and which the Government of the United States, with unprecedented forbearance, had striven to maintain. Serious as such a step is, it is approved and sustained by the unanimous opinion of loyal American citizens. It had been provoked by an attitude of indifference to the claims of friendship and the rights of humanity that invalidated all professions of amity, and subsequent revelations of the spirit and designs of the Imperial German Government regarding the territorial integrity of the United States confirm the decision that further intercourse with the Imperial German Government was derogatory to the honor and dignity of the United States.

David J. HiLl.

\title{
LIMITED USE OF FORCE
}

The Special Session Message of President Adams of May 16, 1797, at the time of strained relations between the United States and France, offers suggestive material for comparison with conditions at present confronting the United States. President Adams said: 
The diplomatic intercourse between the United States and France being at present suspended, the Government has no means of obtaining official information from that country. . . . Hitherto I have thought proper to prevent the sailing of armed vessels except on voyages to the East Indies, where general usage and the danger from pirates appeared to render the permission proper. Yet the restriction has originated solely from a wish to prevent collisions with the powers at war, contravening the act of Congress of June, 1794, and not from any doubt entertained by me of the policy and propriety of permitting our vessels to employ means of defence while engaged in a lawful foreign commerce. It remains for Congress to prescribe such regulations as will enable our seafaring citizens to defend themselves against violations of the law of nations, and at the same time restrain them from committing acts of hostility against the powers at war. In addition to this voluntary provision for defense by individual citizens, it appears to me necessary to equip the frigates, and provide other vessels of inferior force, to take under convoy such merchant vessels as shall remain unarmed. . . .

However we may consider ourselves, the maritime and commercial powers of the world will consider the United States of America as forming a weight in that balance of power in Europe which never can be forgotten or neglected. It would not only be against our interest, but it would be doing wrong to one half of Europe, at least, if we should voluntarily throw ourselves into either scale. It is a natural policy for a nation that studies to be neutral to consult with other nations engaged in the same studies and pursuits.

Attorney General Lee, in August, 1798, maintained that there was with France "not only an actual war" but "a maritime war authorized by both nations." In Congress there was not lacking at that time the opinion that there was a state of war between the United States and France. When Congress enacted various measures for defense, Edward Livingston, later to be Secretary of State and Minister to France, said: "Let no man flatter himself that the vote which has been given is not a declaration of war. Gentlemen know that this is the case."

Later, in 1830, his views had changed, and he saw in these earlier events that: "This was not a case of war, and the stipulations which reconciled the two nations was not a treaty of peace; it was a convention for the putting an end to certain differences."

The Acts passed aimed, like that of May 28, 1798 ( 1 Stat. L, 561), "more effectually to protect the commerce and coasts of the United States." Here the President is authorized not to declare war, but to use force because depredation had been committed upon American commerce in contravention of the law of nations. This Act authorized in accord with international law the bringing in for action of vessels which "shall have committed, or which shall be found hovering on the coasts of the United States for the purpose of committing dep- 
redations on the vessels belonging to citizens thereof; and also to retake any ship or vessel of any citizen or citizens of the United States which may have been captured by any such armed vessel." This was distinctly an act to protect the commerce and coasts of the United States.

The Act of June 25, 1798 (1 Stat. L. 572) provided that an American merchant vessel "may oppose and defend itself against any search, restraint, or seizure which shall be attempted upon such vessel." This Act was aimed against attempts by French vessels upon American vessels.

In the case of the Nancy ( 27 Ct. Cl. R. 99) it was said:

It has been urged that the Statutes of the United States authorize resistance by our merchantmen to French visitation and search, to which there is the simple answer that no single State can change the law of nations by its municipal regulations.

This opinion was sustained in 1900 in the case of the Rose $(36 \mathrm{Ct}$. Cl. R. 291), where it was said:

If, therefore, at the time of this seizure there was any conflict between the municipal law of the United States, as exemplified in the statute, and the well-recognized principle of international law, the latter must prevail in the determination of the rights of the parties.

The Rose, after resistance and capture, had been condemned under French law. Chancellor Kent had said:

There may be cases in which the master of a neutral ship may be authorized by the natural right of self-preservation to defend himself against extreme violence threatened by a cruiser grossly abusing his commission; but except in extreme cases a merchant vessel has no right to say for itself, and an armed vessel has no right to say for it, that it will not submit to visitation and search or be carried into a proximate court for inquiry.

In the case of the Rose it was argued

That the condition existing between the two governments and peoples was such that all respect of neutral right had ceased, and that force, fraud, and violence prevailed, and in that connection much is said as to the right of self-defence.

The court, however, stated

The claimants are treading on very dangerous ground when they urge the higher law of self-preservation. Self-defence is founded on the theory that it is the only remedy, and that, being the only remedy, it presupposes the absence of all law protecting the rights of him who asserts the prerogative of self-defence. If the right of self-defence prevailed to the extent of repelling force by force, and was incident 
to the crew of the ship captured, then all other law was silent and war prevailed, which condition would be most disastrous to the case of the claimant.

It was decided that the Rose was not entitled to take the law into its own hands and use force and that the seizure in 1799 and condemnation by the French authorities was lawful.

The Act of July 9, 1798 (1 Stat. L. 578), authorized the President "to instruct the commanders of the public armed vessels which are, or which shall be employed in the service of the United States, to subdue, seize and take any armed French vessel." The same Act authorized the commissioning of private vessels for a similar purpose.

The Act of July 7, 1798, had declared treaties between the United States and France at an end because "there is yet pursued against the United States, a system of predatory violence, infracting the said treaties, and hostile to the rights of a free and independent nation."

There was no declaration of war, but there were acts which might properly be regarded as just cause for war. These acts were acts of reprisal against a specified state, sometimes called a condition of limited use of force.

The use of force has been authorized at other times by Congress, as in the Water Witch affair in 1858, and in the controversy with Venezuela in 1890.

In all cases where force is thus used by state against state it should be borne in mind that, as said by the Court of Claims in 1909, "while reprisals are acts of war in fact, it is for the state affected to determine for itself whether the relation of actual war was intended by them." (The Schooner Endeavor, 44 Ct. Cl. 242.)

George G. Wilson.

\section{SANCTION FOR INTERNATIONAL AGREEMENTS}

Whether or not justified, the lack of confidence in international agreements seems in some quarters to have become more general in recent years. Diplomatic agents, and those particularly concerned with international Felations, seem, however, to have no illusions. In ancient times, and often in modern times, Deity has been called upon to witness agreements between tribal or political unities. In early Grecian tribal agreements, a money penalty was provided if either party failed in its obligations, and the penalty was to go as a tribute to the Olympian Zeus. Hostages were early given, and many other 